\title{
A New Version of Comet Assay
}

DOI: $10.17691 /$ stm2016.8.1.03

Received Jule 13, 2015

I.A. Chernigina, Head of Molecular Biology Laboratory, Department of Biology;

T.G. Shcherbatyuk, DSe, Professor, Head of Biology Department

Nizhny Novgorod State Medical Academy, 10/1 Minin and Pozharsky Square, Nizhny Novgorod, 603005,

Russian Federation

The aim of the investigation was to assess the availability of ozone to induce DNA damage in individual cells when analyzing them using the Comet assay.

Materials and Methods. Experimental studies were performed on whole blood leukocytes of white non-linear intact male rats $(n=16)$ weighing $250 \pm 25 \mathrm{~g}$. Two series of experiments were made to induce DNA damage in leukocytes. During the first series the samples were exposed to gamma-radiation, and during the second series the slides were treated with ozonized phosphate buffer saline. Further the cells were exposed to cytolysis followed by DNA denaturation, electrophoresis, neutralization, DNA being stained with a SYBR GREEN I. Comet visualization (fluorescent microscopy) and scoring were performed.

Results. The new version of the Comet assay was developed. Ozone concentration, $900 \mu \mathrm{g} / \mathrm{L}$, in ozone-oxygen mixture, and the exposure time for $10 \mathrm{~min}$ on the cells on a microscope slides were found to be optimal for detection of DNA damage and its analysis. In addition, ozone application enables to minimize the drawbacks and limitations of gamma-radiation source.

Key words: Comet assay; DNA leukocyte damage; ozone; gamma-radiation.

The Comet assay enables to determine the level of DNA damage and repair in single, non-dividing nucleated cells. The technique was first developed by Ostling and Johansson, Swedish researchers, in 1984 $[1,2]$. Currently, thousands of researches are devoted to the method applied in basic studies, and just dozens of them concern its usage in clinical medicine [1, 3-26] (Figure 1).

There are some reports informing an increased damage level of DNA in peripheral blood leukocytes is found in such diseases as coronary heart disease, diabetes mellitus (type 2), obesity and malignancies [22-26].

There are data reported on determining the basal level of DNA damage in peripheral blood lymphocytes in breast cancer and oropharyngeal cancer, and a variety of solid tumors after radiation, chemotherapy, chemoradiation and after surgical removal of the tumor by mastectomy and quadrantectomy [27-30]. The studies have demonstrated the high level of DNA damage, which the authors consider to be a serious risk factor of cancer recurrence.

Taube et al. [31] in their literature review concerned with the criteria of a new method used for cancer detection maintain that any new diagnostic technique must pass three main tests before it is approved for routine usage in clinical practice. Firstly, it must be well established and reproducible; secondly, the clinical applicability of a technique must be proved (i.e. with the use of this method a correct diagnosis is should be made resulting in patient's health improvement); and, thirdly, the medical community must be convinced in the necessity for the technique use and the advantages it exhibits.

According to European scientists [32, 33], the Comet assay due to its availability can be used in clinical practice: $50-100$ single nucleated cells are sufficient to analyze the DNA damage and repair. Moreover, and not least, the technique is actually an instant diagnostic test: the test results can be obtained within a few hours. However, despite the advantages, the Comet assay nowadays is still not used as a standard analytical approach in clinical laboratories. And one of the reasons is the presence of some technical difficulties, which prevent from well within-assay reproducibility [32, 33].

Currently, researchers induce DNA damage in individual cells on slides by X-ray and gamma-radiation $[1,4,34-37]$. To provide the approach, a number of technical requirements should be satisfied; the requirements limiting a wide applicability of the Comet assay in practical medicine [38].

In a special issue of Oxford journal "Mutagenesis" Andrew R. Collins, Professor of Norwegian University of Fundamental Medicine, calls for scientists to report the data on the development and updating the technique, and its application in relatively new or unstudied fields of researches [39].

For contacts: Tatiana G. Shcherbatyuk, e-mail: ozone_stg@mail.ru 


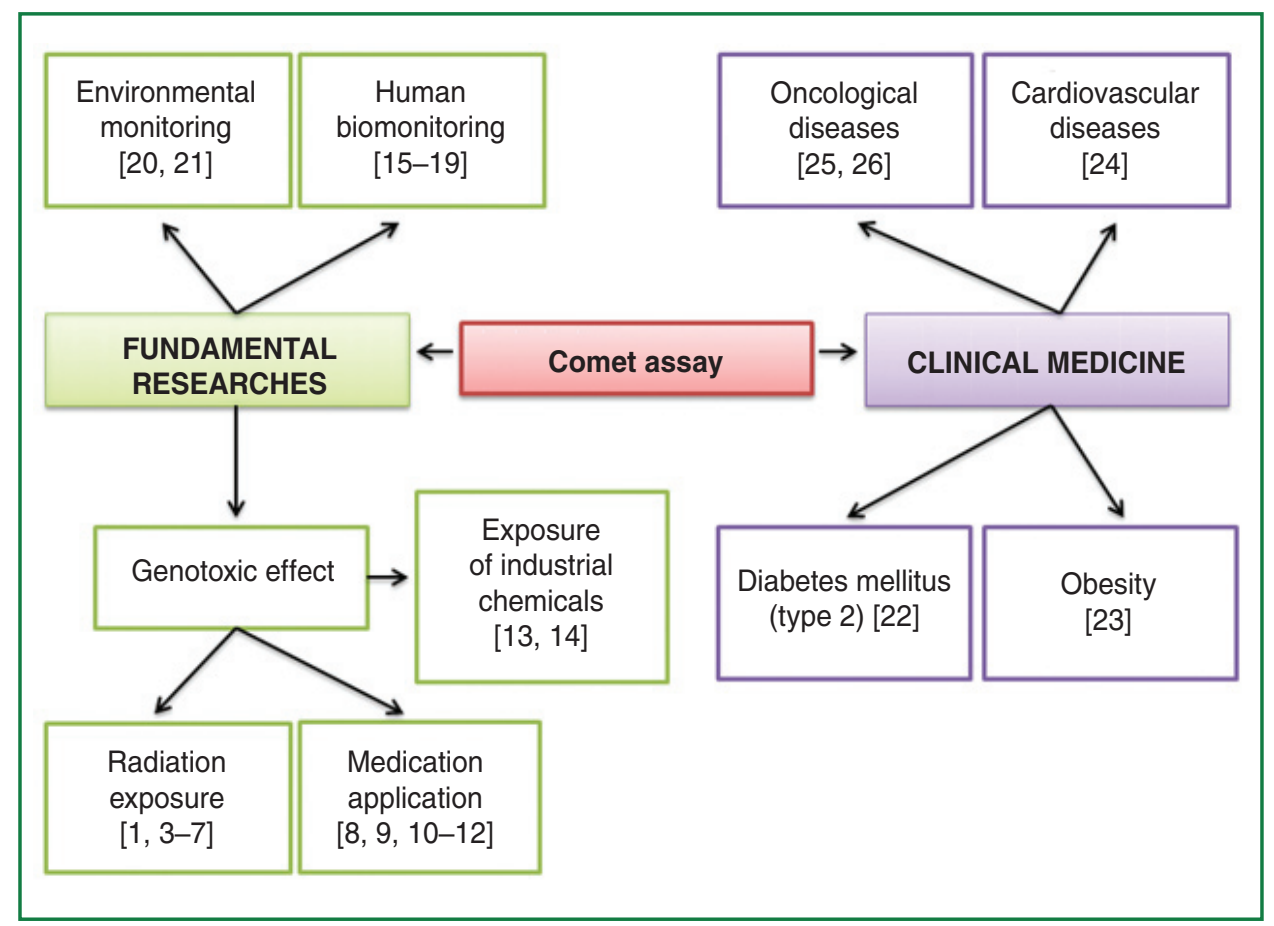

Figure 1. The main directions of the application of Comet assay in biomedical research

The abovementioned determines the relevance of the search of a new method modification to induce DNA damages in individual cells using the Comet assay.

The aim of the investigation was to assess the availability of ozone to induce DNA damage in individual cells to analyze them using the Comet assay.

Materials and Methods. Experimental studies were performed on whole blood leukocytes of 16 white nonlinear intact male rats weighing $250 \pm 25 \mathrm{~g}$.

The work was performed in accordance with ethical principles established by European Convention for the Protection of Vertebrata used for Experimental and other Scientific Purposes (the Convention was passed in Strasburg, March, 18, 1986, adopted in Strasburg, June, $15,2006)$ and approved by Ethics Committee of Nizhny Novgorod State Medical Academy.

The blood $(20 \mu \mathrm{l})$ was drawn via sublingual vein and mixed with $500 \mu \mathrm{l}$ of $0.5 \%$ low-melt-point agarose. Final leukocyte concentration in the solution was 500,000 cells/ $\mathrm{ml}$. Such hemodilution is optimal for the comets under study to be equally spaced in field of vision on the slide. Further, the slides with individual cells in agarose gel we prepared. The slide was applied by the layer of $1 \%$ high-melting agarose, and dried at room temperature for better adhesion of the following layers applied [9, 40]. The suspension of cells mixed with $500 \mu \mathrm{l}$ of $0.5 \%$ lowmelt-point agarose was applied onto solidified layer of $1 \%$ high-melting agarose ( 2 drops per the glass), and covered with cover slips, $24 \times 24 \mathrm{~mm}$ in size. Thus, on each glass there were 2 slides with immobilized cells in the agarose layer. Then, after the solidification of slides for 4-5 min at room temperature, the cover slips were removed for further manipulations with the cells in the agarose layer.

Two series of experiments were carried out according to the original scheme shown in Figure 2 for the induction of DNA damage in leukocytes on the slides.

The main procedures of slide treatment: lysis of cells in agarose gel composition (1 h), DNA denaturation, electrophoresis $(\mathrm{pH}>13)$, neutralization, and DNA staining with a SYBR GREEN I were carried out as described in the paper [4]. After staining the images of comets were photographed, mainly, in the central part of the slides, where the comets were arranged in the same plane.

The photographs were taken with a digital camera model DS series DS-Fi2 (Nikon Corporation, Japan) connected to a direct microscope Nikon Eclipse Ni-U (Nikon Corporation, Japan). The received images were processed with specialized software Comet.exe developed by Stepanov for recording and analyzing displays [41]. The 68 slides on 34 glasses were prepared in experiment totally. The 100 comets from glass have been analyzed, and average value for each experimental point was calculated. For DNA damage degree assessment we used the parameter of \%TDNA, the percentage of DNA in the tail of the comet [1]. Unexposed cells served as control. The data were analyzed using software packages of Microsoft Excel 2010 and AtteStat. 


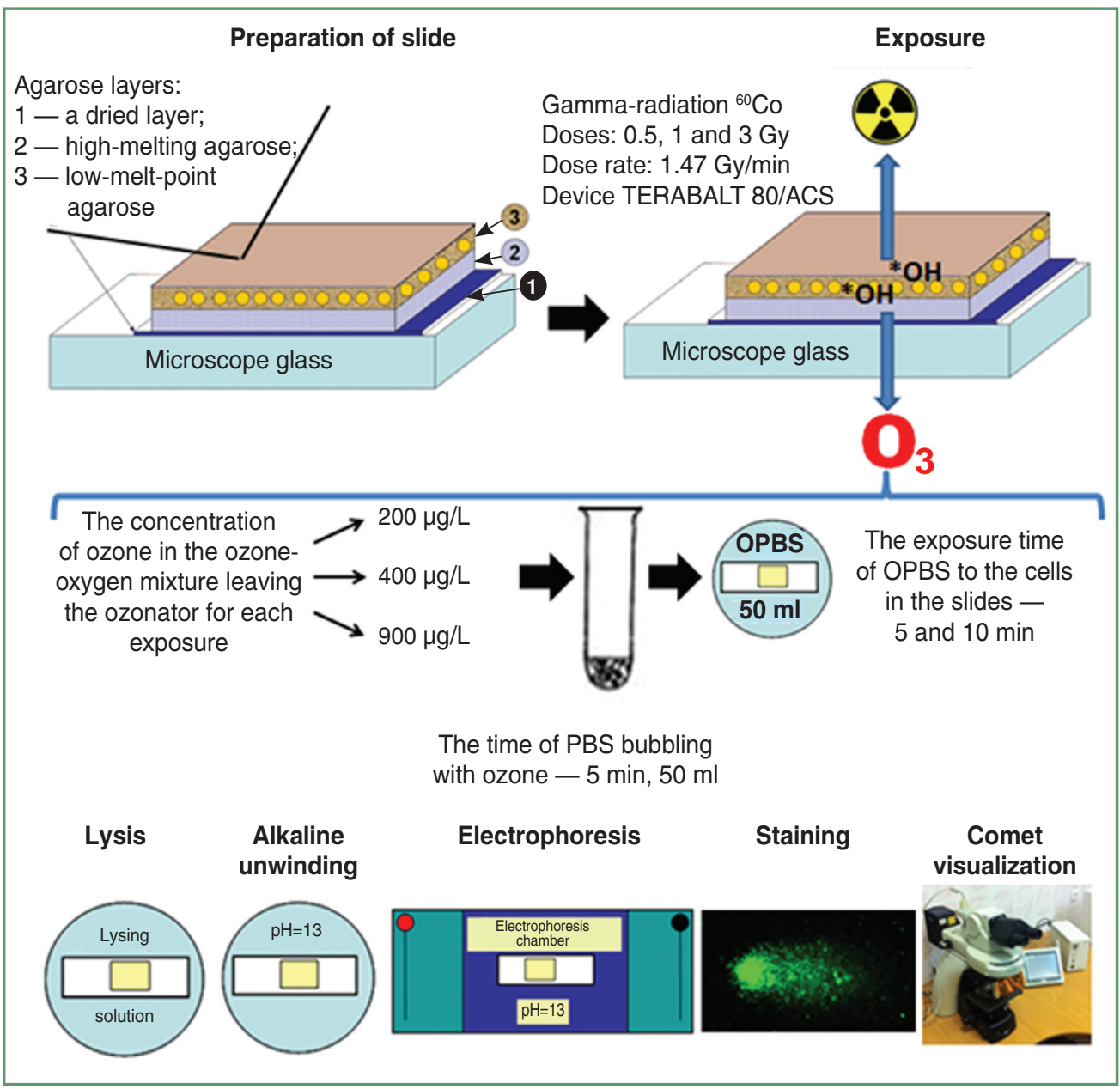

Figure 2. The scheme of induction of DNA damage in leukocytes on the slides at one of the stages of the Comet assay. PBS: phosphate buffer saline; OPBS: ozonized PBS

Results and Discussion. The exposure of ionizing radiation to cells is known to be divided into direct and indirect. In the first instance, radiation interacts directly with the cell components particularly DNA and its damage disrupts the normal functioning of the cell or causes its death. In case of the indirect effect, the radiation interacts with water molecules, which constitute about $80 \%$ of the cell that leads to its radiation the radiolysis of water. This process results in the formation of free radicals particularly the highly reactive hydroxyl radical $\mathrm{OH}^{\cdot}$ that has some strong cytotoxic activity $[42,43]$.

Ozone reacts with the double bonds of the nitrogenous bases of nucleic acids, forming ozonides that ultimately lead to the formation of single- or doublestrand breaks in spirals $[44,45]$. In water solution, the spontaneous decomposition of ozone and its reaction with the hydroxyl ions $\mathrm{OH}^{-}$which is formed in the water due to the dissociation of some part of its molecules. Hydroxyl ion easily and quickly reacts with ozone following rather complex multi-step mechanism with the formation of free radicals $\mathrm{OH}^{*}$ and $\mathrm{OH}_{2}{ }^{*}$ [46]. $\mathrm{OH}^{\cdot}$ radicals in turn react with deoxyribose, being part of the nucleic acids, and this interaction underlies the mutagenic activity of hydroxyl radicals. Besides, hydroxyl radicals react with purine and pyrimidine bases of nucleic acids. It can lead to disruption of complementary bases in the DNA chain and ultimately cause cell mutation or death [44].

Thus, the mechanism of action of the ionizing radiation and ozone on cell DNA is similar: in both cases there is an oxidative stress providing some excessive production of the hydroxyl radical $\mathrm{OH}^{\circ}$.

The features in the morphology of comets are detected after the exposure causing DNA damage.

The nucleoids of unexposed cells have spherical form with a luminous "halo" around the core part. "Halo" is DNA loops attached to the proteins of nuclear matrix [47] (Figure 3). The comets obtained after exposure to ozone in the ozone-oxygen mixture at the concentration $900 \mu \mathrm{g} / \mathrm{L}$ for $5 \mathrm{~min}$ on the cells in the slides had short tail containing some different DNA fragments (Figure 4). 


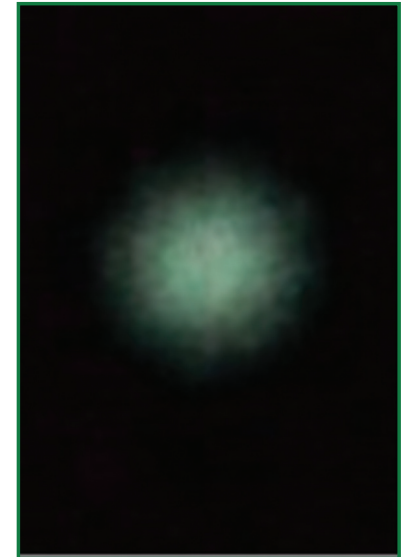

Figure 3. The photomicrograph of the cell nucleoid without exposure $(\%$ TDNA $=0.9) ; \times 200$

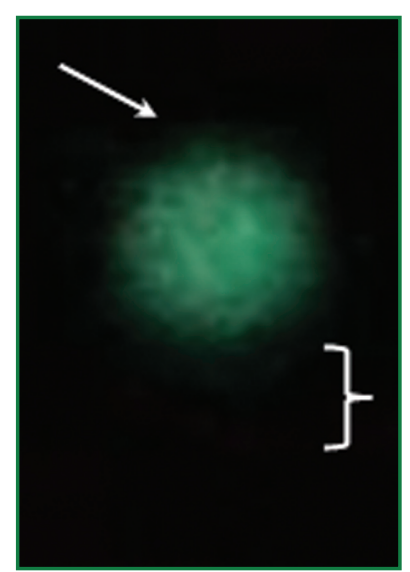

Figure 4. The photomicrograph of the cell nucleoid after exposure with ozone $900 \mu \mathrm{g} / \mathrm{L}$ for $5 \mathrm{~min}(\% T D N A=4.6) ; \times 200$. The arrow indicates the comet head, and the tail length is marked by a curly bracket

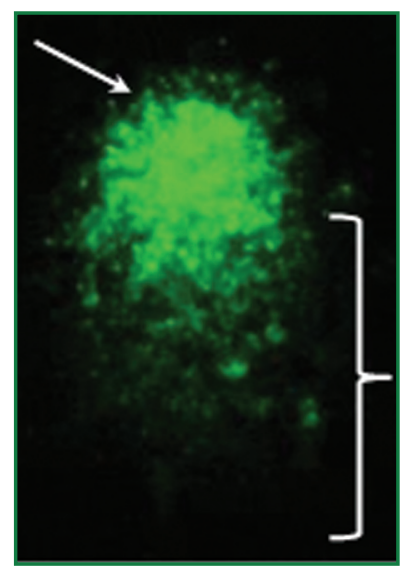

Figure 5. The photomicrograph of the cell nucleoid after exposure with ozone $900 \mu \mathrm{g} / \mathrm{L}$ for $10 \mathrm{~min}$ (\%TDNA=12.6); $\times 200$. The arrow indicates the comet head, and the tail length is marked by a curly bracket

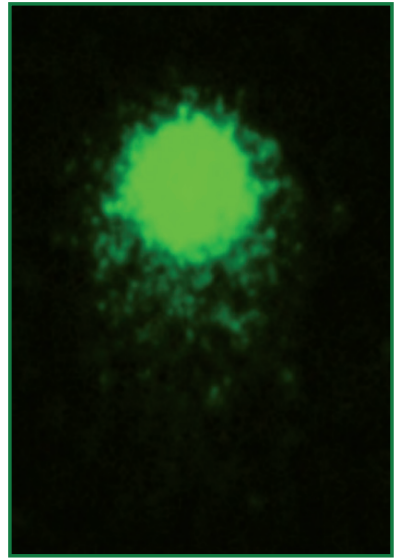

Figure 6. The photomicrograph of the cell nucleoid after exposure with gamma-radiation at the dosage 3 Gy $(\%$ TDNA=12.4); $\times 200$

The cell nucleoids after exposure with ozone at the same concentration, $900 \mu \mathrm{g} / \mathrm{L}$, but for $10 \mathrm{~min}$, had the well-defined long tail (Figure 5). The Figures 3 and 4 are processed using the function Auto built in the microscope. It allows adjusting the brightness of the image to provide the best color reproduction object.

The comparison of photomicrographs of nucleoids of cells obtained after the effect (See Figure 5) and gammaradiation at a dose of 3 Gy (Figure 6) showed Comet assay to have similar long and well-defined tails in both methods of induced DNA damage.

The analysis of the distribution of sample data according to Kolmogorov-Smirnov criterion showed the absence of differences of a normal distribution. Therefore, parametric Student t-test with Bonferonni correction for multiple comparisons were used later. The analysis of the results of the investigations didn't reveal any significant differences of average values of the level induced DNA damage in whole blood leukocytes after exposure with ozone at various concentrations in ozone-oxygen mixture: 200,400 and $900 \mu \mathrm{g} / \mathrm{L}$ for $5 \mathrm{~min}$ (Figure 7). However, the level of induced DNA damage in blood leukocytes after exposure with ozone at the concentration of $900 \mu \mathrm{g} / \mathrm{L}$ for $10 \mathrm{~min}$ was significantly higher than the DNA damage resulted from ozone exposure at all three concentrations for $5 \mathrm{~min}$, and at the concentrations of 200 and $400 \mu \mathrm{g} / \mathrm{L}$ for $10 \mathrm{~min}$.

The comparison of mean levels of induced DNA damage in whole blood leukocytes after exposure with ozone in ozone-oxygen mixture at the concentration of $900 \mu \mathrm{g} / \mathrm{L}$ for $10 \mathrm{~min}(\% \mathrm{TDNA}=12.4 \pm 1.3)$ and after the action of gamma-radiation ${ }^{60} \mathrm{Co}$ at the dosage $3 \mathrm{~Gy}$ (\%TDNA 12.5 \pm 0.4$)$, were not detected significant differences (Figure 8).

Thus, the substitution of gamma-radiation for ozonation to detect DNA damage and repair helps to remove methodological difficulties restricting a wide use of the Comet assay in practical medicine. 


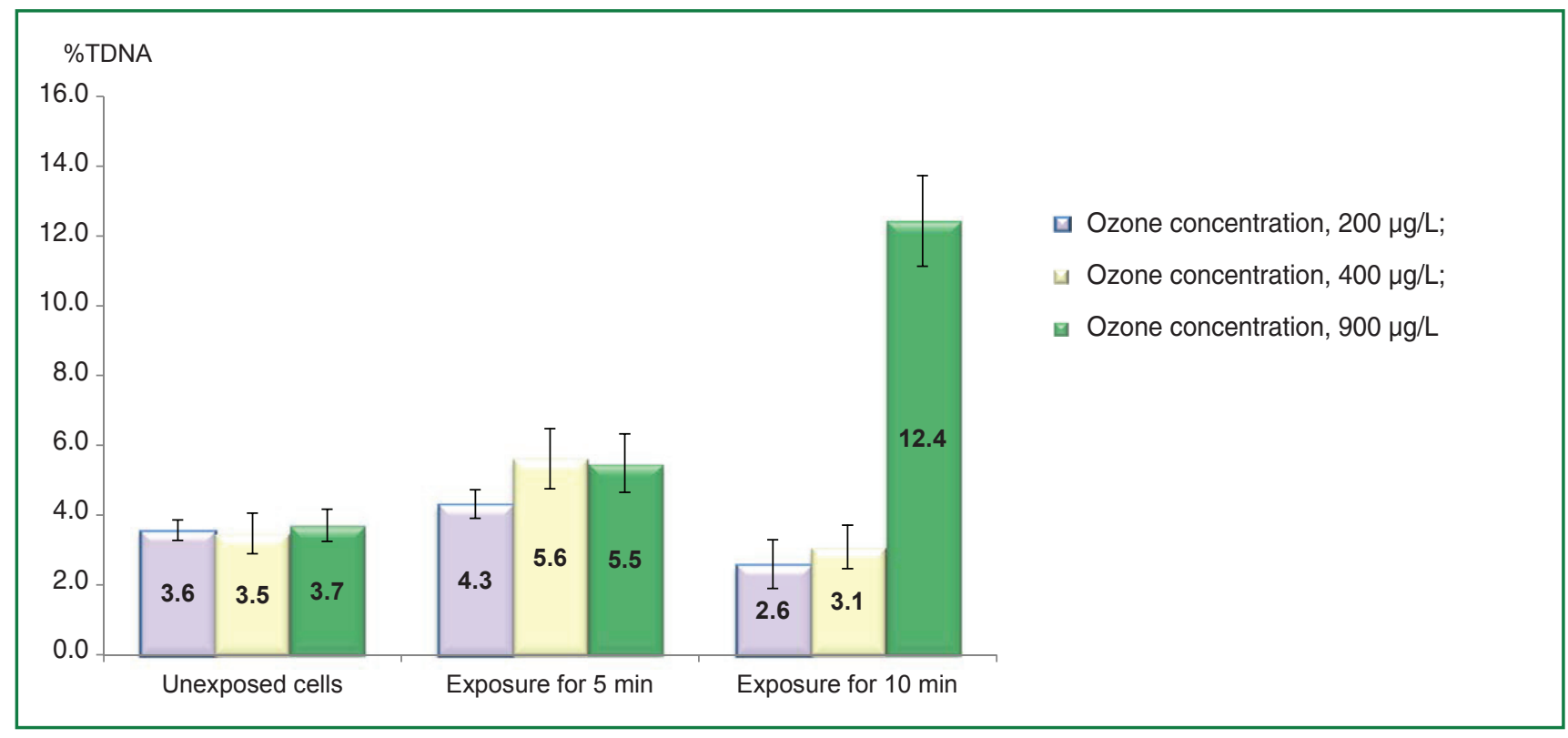

Figure 7. The dependence of the average value of the level induced DNA damage in leukocytes of whole blood of rats on the exposure time with different concentrations of ozone in the ozone-oxygen mixture to the cells in the slides

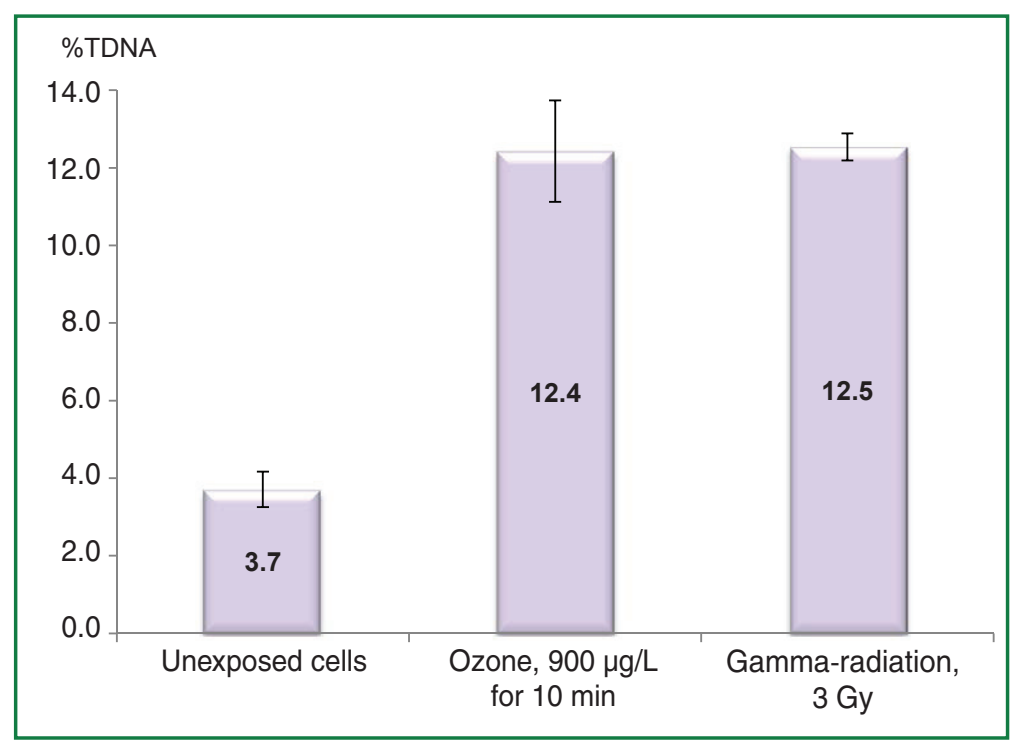

Figure 8. The average value of the level induced DNA damage in leukocytes of whole blood cells after exposure with ozone at the concentrations of $900 \mu \mathrm{g} / \mathrm{L}$ for $10 \mathrm{~min}$ and gamma-radiation at the dosage of $3 \mathrm{~Gy}$ to the cells in the slides
Conclusion. A new version of the Comet assay technique has been developed. The effect of ozone on cells on slides, when ozone concentration in ozoneoxygen mixture is $900 \mu \mathrm{g} / \mathrm{L}$ and exposure time is $10 \mathrm{~min}$, seems to be an optimal to apply the technique to detect and study DNA damage. The proposed approach enables us to avoid the drawbacks of traditional gammaradiation usage.

Acknowledgements. The authors thank to the researchers of the Institute of Theoretical and Experimental Biophysics, Russian Academy of Science (Pushchino, Moscow region): Nikolay P. Sirota, the Senior Researcher, and Elena A. Kuznetsova, PhD, for helping in developing the Comet assay, and important instructions; and Alexey A. Radaev, PhD, the Researcher of Lobachevsky State University of Nizhni Novgorod for consulting on the statistical processing of the results of research.

Study Funding and Conflicts of Interest. The study was not funded by any sources, and the authors have no conflicts of interest related to the present study.

\section{References}

1. Sirota N.P., Kuznetsova E.A. The application of comet assay in radiobiological studies. Radiatsionnaya biologiya. Radioekologiya 2010; 50(3): 329-339. 
2. Liao W., McNutt M.A., Zhu W.G. The comet assay: a sensitive method for detecting DNA damage in individual cells. Methods 2009; 48(1): 46-53, http://dx.doi.org/10.1016/ j.ymeth.2009.02.016.

3. Pelevina I.I., Antoshchina M.M., Bondarenko V.A., Vorob'eva N.Yu., Voronkov Yu.I., Gotlib V.Ya., Kudryashova O.V., Osipov A.N., Ryabchenko N.I., Serebryanyy A.M., Tsetlin V.V. Individual cytogenetic and biomolecular characteristics of blood leukocytes of pilots and cosmonauts. Radiatsionnaya biologiya. Radioekologiya 2007; 47(2): 141-150.

4. Khaimovitch T.I., Nagiba V.I., Nikanorova E.A., Kalinovskaya O.V., Ivanov K.Yu., Patochka G.L. Reparative status and conformational state of blood cell chromatin among nuclear professionals, handling tritium and tritium oxide. Ekologicheskiy vestnik 2010; 12(2): 84-94.

5. Gaziev A.I. Low repair efficiency of critical DNA damage caused by small doses. Radiatsionnaya biologiya. Radioekologiya 2011; 51(5): 512-529.

6. Osipov A.N., Smetanina N.M., Pustovalova M.V., Arkhangelskaya E., Klokov D. The formation of DNA singlestrand breaks and alkali-labile sites in human blood lymphocytes exposed to 365-nm UVA radiation. Free Radic Biol Med 2014; 73: 34-40, http://dx.doi.org/10.1016/j.freeradbiomed.2014.04.027.

7. Hornhardt S., Rößler U., Sauter W., Rosenberger A., Illig T., Bickeböller H., Wichmann H.E., Gomolka M. Genetic factors in individual radiation sensitivity. DNA Repair (Amst) 2014; 16: 54-65, http://dx.doi.org/10.1016/j.dnarep.2014.02.001.

8. Kotova E.V., Sergienko T.F., Ivanova M.A., Smol'nikova V.V., Glushen S.V., Merkulova I.P., Svirnovskiy A.I. The effect of cisplatin on DNA break repair in human peripheral blood lymphocytes. Meditsinskiy zhurnal 2006; 2(16): 1-5.

9. Durnev A.D., Zhanataev A.K., Anisina E.A., et al. Primenenie metoda shchelochnogo gel'-elektroforeza izolirovannykh kletok dlya otsenki genotoksicheskikh svoystv prirodnykh $i$ sinteticheskikh soedineniy [The application of alkaline gel-electrophoresis of isolated cells to assess genotoxic characteristics of natural and synthetic compounds]. Moscow: Poligrafservis; 2006.

10. Ordzhonikidze K.G., Zanadvorova A.M., Abilev S.K. Organ specificity of the genotoxic effects of cyclophosphane and dioxidine: an alkaline comet assay study. Russian Journal of Genetics 2011; 47(6): 754-756, http://dx.doi.org/10.1134/ s1022795411050127.

11. Recio L., Hobbs C., Caspary W., Witt K.L. Witt dozeresponse assessment of four genetoxic chemecals in a combined mouse and rat micronucleus and comet assay. Toxicol Sci 2010; 35(2): 149-162.

12. Braz M.G., Mazoti M.Á., Giacobino J., Braz L.G., Golim Mde A., Ferrasi A.C., de Carvalho L.R., Braz J.R., Salvadori D.M. Genotoxicity, cytotoxicity and gene expression in patients undergoing elective surgery under isoflurane anaesthesia. Mutagenesis 2011; 26(3): 415-420, http://dx.doi. org/10.1093/mutage/geq109.

13. Sorochinskaya U.B., Mikhaylenko V.M. The application of DNA-comet assay to assess DNA damages resulted from various environmental agents. Onkologiya 2008; 10(3): 303-309.

14. García-Lestón J., Roma-Torres J., Vilares M., Pinto R., Prista J., Teixeira J.P., Mayan O., Conde J., Pingarilho M., Gaspar J.F., Pásaro E., Méndez J., Laffon B. Genotoxic effects of occupational exposure to lead and influence of polymorphisms in genes involved in lead toxicokinetics and in DNA repair. Environment International 2012; 43: 29-36, http:// dx.doi.org/10.1016/j.envint.2012.03.001.
15. Pacini S., Giovannelli L., Gulisano M., Peruzzi B., Polli G., Boddi V., Ruggiero M., Bozzo C., Stomeo F., Fenu G., Pezzatini S., Pitozzi V., Dolara P. Association between atmospheric ozone levels and damage to human nasal mucosa in Florence, Italy. Environ Mol Mutagen 2003; 42(3): 127-135, http://dx.doi.org/10.1002/em.10188.

16. Faust F., Kassie F., Knasmüller S., Boedecker R.H., Mann M., Mersch-Sundermann V. The use of the alkaline comet assay with lymphocytes in human biomonitoring studies. Mutat Res 2004; 566(3): 209-229, http://dx.doi.org/10.1016/ j.mrrev.2003.09.007.

17. Szeto Y.T., Benzie I.F., Collins A.R., Choi S.W., Cheng C.Y., Yow C.M., Tse M.M. A buccal cell model comet assay: development and avaluation for human biomonitoring and nutritional studies. Mut Res 2005; 578(1-2): 371-381, http://dx.doi.org/10.1016/j.mrfmmm.2005.06.014.

18. Dusinska M., Collins A.R. The comet assay in human biomonitoring: gene-environment interactionset. Mutagenesis 2008; 23(3): 191-205, http://dx.doi.org/10.1093/mutage/ gen007.

19. Stcherbatyuk T.G., Davydenko D.V., Novikova V.A. Oxidative stress level and anthropogenic load index as prognostic criteria of disease outcome in patients with oropharyngeal cancer. Sovremennye tehnologii $v$ medicine 2013; 5(4): 25-32.

20. Skalskiy S.V., Stupakova L.V., Roskoshnaya D.V., Turchaninov D.V., Poleschuk E.I., Okhlopkov V.A., Govorukha Yu.S. Comet assay prospects in biomonitoring technology and assessment of environmental. Sovremennye problemy nauki $i$ obrazovaniya 2015; 3: 1-6.

21. Lee R.F., Steinert S. Use of single cell gel electrophoresis/ comet assay for detecting DNA damage in aquatic (marine and freshwater) animals. Mutat Res 2003; 544(1): 43-64, http:// dx.doi.org/10.1016/S1383-5742(03)00017-6.

22. Blasiak J., Arabski M., Krupa R., WozniakK., Zadrozny M., Kasznicki J., Zurawska M., Drzewoski J. DNA damage and repair in type 2 diabetes mellitus. Mutat Res 2004; 554(1-2): 297-304, http://dx.doi.org/10.1016/j.mrfmmm.2004.05.011.

23. Harangi M., Remenyik E.E., Seres I., Varga Z., Katona E., Paragh G. Determination of DNA damage induced by oxidative stress in hyperlipidemic patients. Mutat Res 2002; 513(1-2): 17-25, http://dx.doi.org/10.1016/S1383-5718(01)00285-6.

24. Demirbag R., Yilmaz R., Kocyigit A. Relationship between DNA damage, total antioxidant capacity and coronary artery disease. Mut Res 2005; 570(2): 197-203, http://dx.doi. org/10.1016/j.mrfmmm.2004.11.003.

25. Sánchez P., Peñarroja R., Gallegos F., Bravo J.L., Rojas E., Benítez-Bribiesca L. DNA damage in peripheral lymphocytes of untreated breast cancer patients. Arch Med Res 2004; 35(6): 480-483, http://dx.doi.org/10.1016/ j.arcmed.2004.11.008.

26. Sigurdson A.J., Hauptmann M., Alexander B.H., Doody M.M., Thomas C.B., Struewing J.P., Jones I.M. DNA damage among thyroid cancer and multiple cancer cases, controls, and long-lived individuals. Mutat Res 2005; 586(2): 173-188, http://dx.doi.org/10.1016/j.mrgentox.2005.07.001.

27. Gamulin M., Garaj-Vrhovac V., Kopjar N. Evaluation of DNA damage in radiotherapy-treated cancer patients using the alkaline comet assay. Coll Antropol 2007; 31(3): 837-845.

28. Gamulin M., Kopjar N., Grgić M., Ramić S., Bisof V., Garaj-Vrhovac V. Genome damage in oropharyngeal cancer patients treated by radiotherapy. Croat Med J 2008; 49(4): 515527, http://dx.doi.org/10.3325/cmj.2008.4.515. 
29. Gamulin M., Garaj-Vrhovac V., Kopjar N., Ramić S., Viculin T., Juretić A., Grgić M. DNA and cytogenetic damage in white blood cells of postmenopausal breast cancer patients treated with radiotherapy. J Environ Sci Health A Tox Hazard Subst Environ Eng 2010; 45(3): 292-304, http://dx.doi.org/10.10 80/10934520903467881.

30. Sánchez-Suárez P., Ostrosky-Wegman P., GallegosHernández F., Peñarroja-Flores R., Toledo-García J., Bravo J.L., Del Castillo E.R., Benítez-Bribiesca L. DNA damage in peripheral blood lymphocytes in patients during combined chemotherapy for breast cancer. Mutat Res 2008; 640(1-2): 8-15, http://dx.doi. org/10.1016/j.mrfmmm.2007.11.008.

31. Taube S.E., Jacobson J.W., Lively T.G. Cancer diagnostics: decision criteria for marker utilization in the clinic. Am J Pharmacogenomics 2005; 5(6): 357-364, http://dx.doi. org/10.2165/00129785-200505060-00003.

32. McKenna D.J., McKeown S.R., McKelvey-Martin V.J. Potential use of the comet assay in the clinical management of cancer. Mutagenesis 2008; 23(3): 183-190, http://dx.doi. org/10.1093/mutage/gem054.

33. Fikrová P., Štětina R., Hronek M., Hyšpler R., Tichá A., Zadák Z. Application of the comet assay method in clinical studies. Wien Klin Wochenschr 2011; 123(23-24): 693-699, http://dx.doi.org/10.1007/s00508-011-0066-0.

34. Tronov V.A., Grin'ko E.V., Beritashvili D.R., Filippovich I.V. Microelectrophoresis DNA individual intact and gamma-radiated thymocytes. Tsitologiya 1991; 33(2): 94-102.

35. Chaubey R.C., Bhilwade H.N., Rajagopalan R., Bannur S.V. Gamma ray induced DNA damage in human and mouse leucocytes measured by SCGE-Pro: a software developed for automated image analysis and data processing for Comet assay. Mutat Res 2001; 490(2): 187-197, http:// dx.doi.org/10.1016/S1383-5718(00)00166-2.

36. Lankoff A., Bialczyk J., Dziga D., Carmichael W.W., Gradzka I., Lisowska H., Kuszewski T., Gozdz S., Piorun I., Wojcik $A$. The repair of gamma-radiation - induced DNA damage is inhibited by microcystin - LR, the PP1 and PP2A phosphatase inhibitor. Mutagenesis 2006; 21(1): 83-90, http:// dx.doi.org/10.1093/mutage/gel002.

37. Vorob'eva Nlu., Antonenko A.V., Osipov A.N. Particularities of blood lymphocyte response to irradiation in vitro in breast cancer patients. Radiats Biol Radioecol 2011; 51(4): 451-456.
38. Trebovaniya radiatsionnoy bezopasnosti pri proizvodstve, ekspluatatsii $i$ vyvode iz ekspluatatsii (utilizatsii) meditsinskoy tekhniki, soderzhashchey istochniki ioniziruyushchego izlucheniya. Postanovlenie Glavnogo gosudarstvennogo sanitarnogo vracha RF 91 ot 07.07.2011 [Radiation safety requirements in the production, operation and retirement from operation (utilization) of medical equipment containing ionizing radiation sources. The Resolution of Chief State Medical Officer of the Russian Federation No.91 dated 07.07.2011].

39. Collins A.R. The comet assay: a heavenly method! Mutagenesis 2015; 30(1): 1-4, http://dx.doi.org/10.1093/mutage/ geu079.

40. Speit G., Hartmann A. The comet assay: a sensitive genotoxicity test for the detection of DNA damage and repair. Methods Mol Biol 2006; 314: 275-286, http://dx.doi. org/10.1385/1-59259-973-7:275.

41. Stepanov V.N. Metody i programmnye sredstva avtomatizatsii analiza izobrazheniy mediko-biologicheskikh mikroob"ektov. Avtoref. dis. ... kand. tekhn. nauk [The techniques and software tools for automation of image analysis of biomedical micro-objects. PhD Thesis]. Moscow; 2005.

42. Kiseleva E.S., Goldobenko G.V., Kanaev S.V., et al. Luchevaya terapiya zlokachestvennykh opukholey [Radiation therapy of malignant tumors]. Kiseleva E.S. (editor). Moscow: Meditsina; 1996; 464 p.

43. Il'in L.A., Kirillov V.F., Korenkov I.P. Radiatsionnaya bezopasnost' i zashchita [Radiation safety and protection]. Moscow: Meditsina; 1996; $336 \mathrm{p}$.

44. Men'shchikova E.B., Lankin V.Z., Zenkov N.K., et al. Okislitel'nyy stress. Prooksidanty i antioksidanty [Oxidative stress. Prooxidants and antioxidants]. Moscow: Slovo; 2006; 556 p.

45. Viebahn-Hänsler R., León Fernández O.S., Fahmy Z. The low-dose ozone concept - guidelines and treatment strategies. Ozone: Science \& Engineering Journal 2012; 34(6): 408-424.

46. Razumovskii S.D., Konstantinova M.L., Grinevich T.V., Korovina G.V., Zaitsev V.Ya. Brutto - law of ozone decomposition in physiologic solutions and a method of evaluation of ozone dose really introduced to paitients together with solution volume. Biomeditsinskaya khimiya 2010; 56(3): 380-386, http://dx.doi.org/10.18097/pbmc20105603380.

47. Tronov V.A., Nikol'skaya T.A., Konoplyannikov M.A. DNA comets as markers of cells death. Biofizika 1999; 44(2): 288-295. 